\title{
Assessment of Impacts of Climate Change on Tile Discharge and Nitrogen Yield Using the DRAINMOD Model
}

\author{
Golmar Golmohammadi ${ }^{1, *}$, Ramesh P. Rudra ${ }^{1}$, Gary W. Parkin ${ }^{2}$, Priyantha B. Kulasekera ${ }^{2}$, Merrin Macrae ${ }^{3}$ and \\ Pradeep K. Goel ${ }^{4}$ (D) \\ 1 School of Engineering, University of Guelph, Guelph, ON N1G 2W1, Canada; rrudra@uoguelph.ca \\ 2 School of Environmental Sciences, University of Guelph, Guelph, ON N1G2W1, Canada; \\ gparkin@uoguelph.ca (G.W.P.); kulasekp@uoguelph.ca (P.B.K.) \\ 3 Department of Geography and Environmental Management, University of Waterloo, \\ Waterloo, ON N2L 3G1, Canada; mmacrae@uwaterloo.ca \\ 4 Ontario Ministry of the Environment, Conservation and Parks, Etobicoke, ON M9P 3V6, Canada; \\ Pradeep.goel@ontario.ca \\ * Correspondence: ggolmoha@uoguelph.ca; Tel.: +1-519-766-6786
}

check for updates

Citation: Golmohammadi, G.; Rudra, R.P.; Parkin, G.W.; Kulasekera, P.B.; Macrae, M.; Goel, P.K. Assessment of Impacts of Climate Change on Tile Discharge and Nitrogen Yield Using the DRAINMOD Model. Hydrology 2021, 8, 1. https://dx.doi.org/ 10.3390/hydrology 8010001

Received: 26 November 2020 Accepted: 21 December 2020 Published: 26 December 2020

Publisher's Note: MDPI stays neutral with regard to jurisdictional claims in published maps and institutional affiliations.

Copyright: () 2020 by the authors. Licensee MDPI, Basel, Switzerland. This article is an open access article distributed under the terms and conditions of the Creative Commons Attribution (CC BY) license (https: / / creativecommons.org/ licenses/by/4.0/).

\begin{abstract}
The detrimental impacts of agricultural subsurface tile flows and their associated pollutants on water quality is a major environmental issue in the Great Lakes region and many other places globally. A strong understanding of water quality indicators along with the contribution of tiledrained agriculture to water contamination is necessary to assess and reduce a significant source of non-point source pollution. In this study, DRAINMOD, a field-scale hydrology and water quality model, was applied to assess the impact of future climatic change on depth to water table, tile flow and associated nitrate loss from an 8.66 ha agricultural field near Londesborough, in Southwestern Ontario, Canada. The closest available climate data from a weather station approximately $10 \mathrm{~km}$ from the field site was used by the Ontario Ministry of Natural Resources and Forestry (MNRF) to generate future predictions of daily precipitation and maximum and minimum air temperatures required to create the weather files for DRAINMOD. Of the 28 models applied by MNRF, three models (CGCM3T47-Run5, GFDLCM2.0, and MIROC3.2hires) were selected based on the frequency of the models recommended for use in Ontario with SRA1B emission scenario. Results suggested that simulated tile flows and evapotranspiration (ET) in the 2071-2100 period are expected to increase by $7 \%$ and $14 \%$ compared to $1960-1990$ period. Results also suggest that under future climates, significant increases in nitrate losses (about 50\%) will occur along with the elevated tile flows. This work suggests that climate change will have a significant effect on field hydrology and water quality in tile-drained agricultural regions.
\end{abstract}

Keywords: field-scale hydrological models; DRAINMOD; tile drainage; nitrate leaching; climate change

\section{Introduction}

Field agriculture is a significant land use in many areas of the world and has been documented as a contributor of non-point source pollution to surface waters. In a recent study in Uruguay, [1] researchers found a strong correlation between total phosphorus (P) and agriculture land use in a river. In central Asia, remote sensing was used to analyze effects of land use on surface water contamination [2]. Although the relationships were not straightforward, they did find that cropland was a significant contributor to surface water organic pollution. In another study in Europe, [3], analyses of nutrients and other components in river water found that the proportion of arable land in the watershed did affect water pollution levels. To further investigate agricultural land use as a non-point source of pollution, the hydrologic pathway of a pollutant from field to surface water body must be identified and quantified. This study focusses on quantifying tile flow and 
accompanying nitrate load to surface waters under future climate conditions of the Great Lakes region of North America.

Subsurface (tile) drainage is considered an effective and important practice in field agricultural water management to facilitate farm operations, especially in cold climatic regions. In Ontario, Canada, more than $50 \%$ of its arable land is under artificial drainage systems [4]. Tile drainage increases productivity of land by increasing crop yields, but also impacts the environment by degrading water quality. Indeed, it is widely recognized that nitrogen $(\mathrm{N})$ and $\mathrm{P}$ leaching results in elevated nutrient concentrations in surface waters representing both environmental and economic (fertilizer loss) impacts. High levels of nitrate may even remain in tile drainage several years after nitrogen fertilizer reduction $([5,6])$. Hence, to reduce contamination of surface waters, the impacts of changing cropping systems that may, for instance, occur under future climate regimes are essential. Although climate change is anticipated to play an important role in subsurface drainage, it is not possible to characterize the potential impacts of climate change on field hydrology and/or water quality in agricultural watersheds using field observations. However, modeling of these potential impacts does have potential to at least give acceptable trends in future tile flow and associated nitrate loss. For instance, [7] used the Root Zone Water Quality Model (RZWQM) to estimate the impact of agricultural management systems adaptations on gaseous and drainage nitrogen $(\mathrm{N})$ losses in Iowa, USA. They found that the optimal $\mathrm{N}$ rate to minimize loss and maximize maize production was $120 \mathrm{~kg} \mathrm{~N} \mathrm{ha}^{-1}$. Using DRAINMOD, researchers [8] were able to suggest when to block tile outflow to keep the groundwater table at an acceptable depth in central-western Poland. In Illinois, [9], assessed impacts of changing atmospheric conditions using RZWQM along with Support Decision for Agrotechnology Transfer (DSSAT). They found that increasing rainwater nitrate concentration had a moderate impact on nitrate loss in drainage tiles.

In Canada mainly watershed-scale studies on impacts of climate change on water resources have been completed by [10-14]. In their study on a watershed in Quebec, [10], simulated future streamflows finding a slight decrease in annual runoff. In another study, [11], used a weather generator to recommend local water resource management adaptations for a watershed near the present study's site in Ontario. Using streamflow data and the LARS-WG weather generator, the Soil and Water Assessment Tool (SWAT) model was used by [12] to show that streamflow in a southern Ontario watershed could increase by $12 \%$ compared to base period 1961-1990. Also, in southern Ontario, [13] used model simulations to estimate the increase in winter streamflow in several large watersheds. A future assessment of groundwater nitrate concentrations in a sub-watershed of southern Ontario was conducted by [14]. They found that an agricultural BMP was very effective in reducing nitrate in groundwater under a crop rotation system.

In the Great Lakes region, where this study was conducted, there have been several recent studies on impacts of climate change on tile flow and nutrient losses at the watershed scale. The WEPP-WQ model was used by [15] to estimate future $\mathrm{N}$ and P losses in two small watersheds finding increases in losses of both nutrients. In another study [16], used DRAINMOD to simulate future tile flow in western Lake Erie basin. They found an average decrease of about $9 \%$ in subsurface drainage and recommended controlled drainage to retain more water in the soil profile as a BMP for crop production. In the same basin [17], using the SWAT model found an increase in subsurface drain flow but a decrease in P load from drains. On the other hand, relatively few field-scale studies, which use field data to first calibrate and then validate a tile-flow model to assess climate change impacts have been attempted in the region. Field-scale studies have the advantage over watershed-scale studies of a better-defined source area with associated soil and cropping properties for assessing impacts of future climate on tile flow and accompanying nutrient losses. Using DRAINMOD [18], examined impacts of different tillage practices on future tile flow and nitrate loss in eastern Ontario. They estimated greater future nitrate loss under no-tillage than conventional tillage. At the same field site as the work presented here, The SWAT model was applied to future climate data similar to the approach used in this study [19]. In 
addition, their results indicated a shift in seasonal water balance and an associated increase in annual P losses by year 2100. Main differences between this study and [19] are use of a different model and modeling approach and analysis of $\mathrm{N}$ loss in this study as opposed to $P$ loss in the [19] study.

The DRAINMOD model was developed by [20] as a process-based distributed fieldscale model. Many studies have assessed and applied DRAINMOD including, to name a few [21-24]. The DRAINMOD model has been extensively revised and updated over the years and is still undergoing improvements $[25,26]$. The main reasons why it was chosen for this study are three-fold: it includes impacts of winter-season processes on soil hydrology along with soil nitrogen dynamics and it has been previously tested and proven satisfactory in Ontario and other cold regions (e.g., [18,27-38]). For information on the structure and details on the applied processes in DRAINMOD see publications by $[22,39]$.

Previous work at the same field site as used in this study includes analyses of $\mathrm{P}$ transport by [19,40-44]. As well, [45] examined the contribution of preferential flow to tile drainage.

Based on the preceding literature review, this study was undertaken to address the paucity of field-scale studies of how tile flow and nitrate loss may change under future climate regimes in the Great Lakes region. As climate changes there is the potential for shifts in agricultural practices, which may lead to increased nitrate leaching [46]. Hence more studies such as herein are needed to establish a baseline nitrate loading using current field crop practices. In a recent review by [47], it was noted that it is important to improve field-scale hydrology and water quality models under cold climates found in Canada and elsewhere in high-latitude regions. Studies that apply field data to calibrate and validate models, as done in this study, will lead to improvements in model accuracy in the future.

The objectives of this study were: (1) to calibrate and evaluate the latest version of DRAINMOD 6.1 using data from a field site in southern Ontario; and (2) to assess the impact of climate change on tile discharge and nitrogen yields at the same field site using the calibrated model. Using the CGCM3T47 with SRA1B emission scenario, we estimate the impact of future climate on tile discharge and its accompanying nitrate loading for the next century. This research may assist the farming community in developing adaptation strategies to minimize negative impacts of tile drainage systems on water resources.

\section{Materials and Methods}

\subsection{Description of Study Area}

The study site (LON) is in southern Ontario, Canada (UTM 472219 E and 4767583 N) near Londesborough. The study was conducted on an 8.66 ha agricultural field with both overland flow and tile drainage restricted to the study field. The site was under a reduced overland tillage (RT) and data collection spanned a range of years and therefore experienced a range of climatic conditions. Tile drainage systems in the field are systematically drained at $90 \mathrm{~cm}$ depth through $10-\mathrm{cm}$ diameter laterals (13.5 m spacing) that connected to a larger main tile (20-cm diameter) that exits at the edge of the field. The contributing area to surface drainage within the field is 7.79 ha.

Long-term average annual precipitation measured at Blyth, Ontario, the closest Environment Canada weather station to LON site, is $1247 \mathrm{~mm}$ and long-term mean annual temperatures are $7.2{ }^{\circ} \mathrm{C}$ (https:/ / climate.weather.gc.ca/historical_data/search_historic_ data_e.html). Monthly temperatures vary seasonally across the year, with warm summers and cold winters. Daily maximum and minimum temperatures are variable throughout the year; however, daily mean air temperatures are generally below freezing between December and March. Due to the climate in Ontario, spring planted crops are seeded in early May, whereas fall seeded crops (winter wheat) are planted in September. Harvests are completed by early August (wheat), mid-September (soy) or November (corn).

The topography of the site is gently undulating with slopes ranging from 0.2 to $3.5 \%$ [48]. The field consists of soils from the Perth Clay Loam association [49]. These soils developed on clay loam glacial deposits with imperfect drainage. Soil samples collected at 
the site suggest that the average texture in the top $15 \mathrm{~cm}$ is silt (clay $0.9 \pm 1.3 \%$, silt $75.7 \pm$ $2.1 \%$, sand $23.4 \pm 3.3 \%$ ) [48]. Table 1 gives some basic soil properties for the LON site.

Table 1. Some soil Properties at Londesborough field site.

\begin{tabular}{ccccc}
\hline Soil Properties & & & \\
\hline Depth $(\mathrm{cm})$ & $0-10$ & $10-20$ & 0.25 & $35-150$ \\
\hline $\begin{array}{c}\text { Soil hydraulic } \\
\text { conductivity }(\mathrm{cm} / \mathrm{h})\end{array}$ & 0.26 & 0.07 & 0.26 \\
\hline Soil pH & \multicolumn{3}{c}{$7.7 \pm 0.3$} \\
\hline Organic matter $(\%)$ & \multicolumn{3}{c}{$4.1 \pm 0.7$} \\
\hline
\end{tabular}

\subsection{Model Formulation}

The DRAINMOD model requires different inputs including air temperature and precipitation data, infiltration parameters, soil properties, crop information, and drainage system parameters. These data were used to calculate the relationships among the drained volume and depth to water table (WTD), and relationships between WTD and maximum steady upward flux. Infiltration was simulated using the Green-Ampt equation. Within the model, a soil moisture retention curve for the soil above the tile was used to calculate infiltration parameters as a function of WTD.

The model provides options to the user to use observed ET data or apply daily maximum and minimum temperatures to calculate ET using the Thornthwaite equation. In this study, Thornthwaite approach has been used. Details related to crop management and timing for the study site are given in Table 2.

Table 2. Management practices considered in the study.

\begin{tabular}{|c|c|c|}
\hline Crop & Date & Activity Code \\
\hline Soybeans & $\begin{array}{c}\text { Mid-October } 2010 \\
\text { (assume 15 October 2010) }\end{array}$ & Harvest \\
\hline \multirow[t]{5}{*}{ Winter Wheat } & $\begin{array}{c}\text { Mid-October } 2010 \\
\text { (Considered 16 October 2010) }\end{array}$ & Plant \\
\hline & April 11, 2011 & Red Clover Air Seeded \\
\hline & 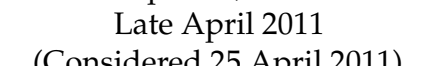 & Fert App \\
\hline & $\begin{array}{c}\text { (Considered 25 April 2011) } \\
\text { Late July } 2011\end{array}$ & \\
\hline & (Considered 25 July 2011) & Harvest \\
\hline \multirow{10}{*}{ Grain Corn } & 5 October 2011 & Fert App \\
\hline & 5 October 2011 & Spray \\
\hline & 11 November 2011 & Tillage \\
\hline & 18 April 2012 & Spray \\
\hline & 25 April 2012 & Tillage \\
\hline & 26 April 2012 & Plant \\
\hline & 26 April 2012 & Fert App \\
\hline & 23 May 2012 & Fert App \\
\hline & 9 June 2012 & Spray \\
\hline & $\begin{array}{l}21 \text { October } 2012 \\
\text { (estimate as no rain that day) }\end{array}$ & Harvest \\
\hline \multirow[t]{4}{*}{ Soybeans } & 9 November 2012 & Tillage \\
\hline & 3 May 2013 & Plant \\
\hline & 24 May 2016 & Spray \\
\hline & 25 September 2013 & Harvest \\
\hline
\end{tabular}


Table 2. Cont.

\begin{tabular}{|c|c|c|}
\hline Crop & Date & Activity Code \\
\hline Winter Wheat & $\begin{array}{l}\text { 27 September } 2013 \\
\text { 19 April } 2014 \\
\text { 26 April } 2014 \\
\text { 1 June } 2014 \\
\text { 7-10 August } 2014\end{array}$ & $\begin{array}{l}\text { Plant } \\
\text { Plant CC } \\
\text { Fert App } \\
\text { Spray } \\
\text { Harvest }\end{array}$ \\
\hline Grain Corn & $\begin{array}{c}9 \text { October } 2014 \\
9 \text { October } 2014 \\
\text { 17 October } 2014 \\
19 \text { April } 2015 \\
27 \text { April } 2015 \\
28 \text { April } 2015 \\
28 \text { April } 2015 \\
\text { May } 15 / 15 \\
\text { (estimate) — check weather station } \\
\text { 25 May } 2015 \\
\text { 15 July } 2015 \\
\text { 17 October } 2015\end{array}$ & $\begin{array}{l}\text { Fert App } \\
\text { Spray } \\
\text { Tillage } \\
\text { Spray } \\
\text { Tillage } \\
\text { Plant } \\
\text { Fert App } \\
\text { Spray } \\
\text { Fert App } \\
\text { Spray } \\
\text { Harvest }\end{array}$ \\
\hline Soybeans & $\begin{array}{c}9 \text { November } 2015 \\
3 \text { May } 2016 \\
\text { 24/05/2016 (estimate)—check } \\
\text { weather station }\end{array}$ & $\begin{array}{l}\text { Tillage } \\
\text { Plant } \\
\text { Spray } \\
\text { Harvest }\end{array}$ \\
\hline
\end{tabular}

Many of the input parameters for DRAINMOD are transferable between sites from nearby cold regions. Hence, parameters related to snow melt, ice content etc. were obtained from the literature, such as [29,30] and [18]. Crop-related constants including nitrogen uptake and transformation factors and organic matter dynamics were taken from $[5,31,33,34,50,51]$.

The lower boundary at $1.2 \mathrm{~m}$ was assumed to be impermeable and at a constant soil temperature of $7{ }^{\circ} \mathrm{C}$, which is approximately the long-term average air temperature [52].

The model requires initial conditions such as concentrations of $\mathrm{NO}_{3}-\mathrm{N}$ and $\mathrm{NH}_{4}^{+} \mathrm{N}$, given in Table 3.

Table 3. Initial nitrogen concentrations in four soil depth ranges at the study site.

\begin{tabular}{cc}
\hline Initial $\mathrm{NO}_{3}-\mathrm{N}$ concentration in soil $\left(\mathrm{mg} \mathrm{L}^{-1}\right)$ & \\
$0-0.15 \mathrm{~m}$ & 5.17 \\
$0.15-0.30 \mathrm{~m}$ & 2.05 \\
$0.30-0.60 \mathrm{~m}$ & 1.62 \\
$0.60-1.20 \mathrm{~m}$ & 1.58 \\
\hline Initial $\mathrm{NH}_{4}^{+}-\mathrm{N}$ concentration in soil $\left(\mathrm{mgl}^{-1}\right)$ & \\
$0-0.15 \mathrm{~m}$ & 3.22 \\
$0.15-0.30 \mathrm{~m}$ & 2.62 \\
$0.30-0.60 \mathrm{~m}$ & 1.74 \\
$0.60-1.20 \mathrm{~m}$ & 1.41 \\
\hline $\mathrm{NH}_{4}^{+}$sorption distribution coefficient & \\
$\left(\mathrm{cm}^{3} \mathrm{~g}^{-1}\right) \mathrm{K} \mathrm{d}$ & \\
$0-0.15 \mathrm{~m}$ & 2.17 \\
$0.15-0.30 \mathrm{~m}$ & 2.32 \\
$0.30-0.60 \mathrm{~m}$ & 2.85 \\
$0.60-1.20 \mathrm{~m}$ & 3.61 \\
\hline
\end{tabular}




\subsection{Model Calibration}

To calibrate and assess the DRAINMOD model, measurements of tile discharge collected in the field from 2011-2016 were divided into two parts: data from the first two years (fall of 2011-summer of 2013), were used to calibrate DRAINMOD, and the remaining two years of the data (fall of 2013-early winter of 2016), were used to validate the model. The chosen calibration parameters were manually adjusted by minimizing differences between observed and simulated tile flow at first visually and then statistically. The most sensitive parameters were selected for calibration based on previous work using DRAINMOD $[18,27,28,32,34-36,50]$. As in other studies, hydrology was first used to calibrate DRAINMOD using $K_{\text {sat }}$ of soil profile and restrictive bottom layer and maximum surface storage which controls water runoff (Table 4).

Table 4. Parameters Used in Calibration of DRAINMOD model.

\begin{tabular}{|c|c|c|c|}
\hline \multicolumn{3}{|c|}{ Parameter } & Value \\
\hline \multicolumn{3}{|c|}{ Saturated hydraulic conductivity (4 layers, $\mathrm{cm} \mathrm{h}^{-1}$ ) } & Varies \\
\hline \multicolumn{3}{|c|}{ Vertical hydraulic conductivity of restrictive layer $\left(\mathrm{cm} \mathrm{h}^{-1}\right)$} & 0.0025 \\
\hline \multicolumn{3}{|c|}{ Maximum surface storage (mm) } & 1.6 \\
\hline \multirow{9}{*}{ Rooting depth $(\mathrm{cm})$} & Month & Day & \\
\hline & 1 & 1 & 5.0 \\
\hline & 5 & 5 & 5.0 \\
\hline & 6 & 15 & 24.0 \\
\hline & 7 & 15 & 36.0 \\
\hline & 7 & 30 & 45.0 \\
\hline & 8 & 31 & 45.0 \\
\hline & 10 & 15 & 5.0 \\
\hline & 12 & 31 & 5.0 \\
\hline \multicolumn{3}{|c|}{ Mineralization rate $\left(\mathrm{d}^{-1}\right)$} & $\begin{array}{l}\text { NT:0.00002 } \\
\text { CT:0.00003 }\end{array}$ \\
\hline \multicolumn{3}{|c|}{ Maximum Nitrification rate $\left(\mu g \mathrm{Ng}^{-1} \mathrm{~d}^{-1}\right)$} & $\begin{array}{l}\text { NT:9.5 } \\
\text { CT:7.7 }\end{array}$ \\
\hline \multicolumn{3}{|c|}{ Nitrification optimum temperature $\left({ }^{\circ} \mathrm{C}\right)$} & 20 \\
\hline \multicolumn{3}{|c|}{ Nitrification half saturation constant $\left(\mu \mathrm{gNg}^{-1} \mathrm{~d}^{-1}\right)$} & 90 \\
\hline \multicolumn{3}{|c|}{ Maximum denitrification rate $\left(\mu g \mathrm{Ng}^{-1} \mathrm{~d}^{-1}\right)$} & $\begin{array}{l}\text { NT:4.0 } \\
\text { CT:3.0 }\end{array}$ \\
\hline \multicolumn{3}{|c|}{ Nitrification empirical shape factor } & 0.5 \\
\hline \multicolumn{3}{|c|}{ Nitrification Optimum temperature $\left({ }^{\circ} \mathrm{C}\right)$} & 23.0 \\
\hline \multicolumn{3}{|c|}{ Nitrification half saturation constant $\left(\mu \mathrm{gNg}^{-1} \mathrm{~d}^{-1}\right)$} & 30.0 \\
\hline
\end{tabular}

Simulations were initially evaluated using visual comparisons between the observed and predicted values. These were subsequently assessed using various statistical parameters. The statistical parameters used were the coefficient of determination $\left(R^{2}\right)$, the percent bias (PBIAS) [53] and the Nash-Sutcliffe efficiency (NSE; [54]). These parameters were calculated according to:

$$
R^{2}=\left[\frac{\sum_{i=1}^{i=n}\left(O_{i}-\bar{O}\right)\left(P_{i}-\bar{P}\right)}{\sqrt{\sum_{i=1}^{i=n}\left(O_{i}-\bar{O}\right)^{2}} \sqrt{\sum_{i=1}^{i=n}\left(P_{i}-\bar{P}\right)^{2}}}\right]^{2}\left(0 \leq R^{2} \leq 1\right)
$$




$$
\begin{aligned}
& \text { PBIAS }=\frac{100 \sum_{i=1}^{i=n} O_{i}-P_{i}}{\sum_{i=1}^{i=n} O_{i}} \\
& N S E=1-\left[\frac{\sum_{i=1}^{i=n}\left(O_{i}-P_{i}\right)^{2}}{\sum_{i=1}^{i=n}\left(O_{i}-\bar{O}\right)^{2}}\right]
\end{aligned}
$$

where, $n$ is the total number of compared values, $O_{i}$ is the $i$ th observed value, $\bar{O}$ is the mean of observed values, $P_{i}$ is the $i$ th predicted value, $\bar{P}$ is the mean of predicted values.

\subsection{Climate Change Simulations}

Global Climate Models (GCM's) or Regional Climate Models (RCM's) are used to generate future climate data needed to assess the possible impacts of future climate changes on drainage and runoff in a watershed. These circulation models are based on physics and provide accurate predictions under different greenhouse gas emission criteria groups, defined by Intergovernmental Panel on Climate Change (IPCC) in their Special Report on Emission Scenarios (SRES) [55] The Ontario Ministry of Natural Resources and Forestry, Canada provided a facility through its web portal Aquamapper (http:/ / climate/aquamapper.com/) to generate future climate data using up to $28 \mathrm{GCMs}$ and RCMs under three gas emission scenarios of SRB1, SRA1B, and SRA2, and SRA2, used in future climate impact studies [56]. Emission scenario SRB1 describes a converging future world with constant population experiencing rapid structural changes towards an economy of service and information by introducing clean and resource-efficient technologies; whereas SRA1B describes a future scenario with rapid economic growth where population peaks at the middle of the century, and rapid introduction of new energy efficient technologies while development is being balanced across energy sources. A highly heterogeneous world with continuously increasing population with a fragmented and slower processing regional economic growth is described by emission scenario SRA2 $[57,58]$.

For this study, we selected the emission scenario presented by SRA1B, which has been recommended for most of the 12 regions of Ontario considered in [23]. SRA1B is also considered to be one of the scenarios across Ontario by Ontario Climate Change Data Portal [59]. This emission scenario assumes the same level of socio-economic-technological growth throughout the region with a rapid economic growth, introduction of efficient new technologies, and has a balance among all energy sources. However, with variable grid sizes of hundreds of kilometers from model to model [60,61], the model predictions may lack the precision needed for smaller sites [62-64].

Since the high coarseness of the spatial $(45 \mathrm{~km})$ and temporal (daily) resolution of the GCMs to represent the physical processes of convection, land atmospheric interactions, and especially in predicting future rainfall intensity-duration-frequency characteristics, downscaling may be needed for obtaining a more accurate picture of the future climate scenario [61,64-66], which we have not attempted in this study.

For this study site near Londesborough, we selected Blyth $\left(43^{\circ} 43^{\prime}, 81^{\circ} 23^{\prime}\right.$, Elevation $=350.5 \mathrm{~m}$ ), the closest weather station presented in Aquamapper, to generate future predictions of daily precipitation, maximum and minimum air temperatures required to create the weather files for DRAINMOD. Out of the 28 models in Aquamapper, three models (CGCM3T47-Run5, GFDLCM2.0, and MIROC3.2 MedRes) were selected based on the frequency of the models recommended for use in Ontario with SRA1B emission scenario. The base data from 1971 to 2000 was used to generate the climate data for 2011-2040, 2041-2070, and 2071-2100.

DRAINMOD was run using the future climate data described above and weather data from 1960-1990 as a comparison. The DRAINMOD input parameters from the calibration exercise, also described above, were used in all simulations. By using the pre-existing 
soil properties and agricultural management system, the future simulations should yield differences between past and future tile flow and nitrate loading only due to climate change.

\section{Results and Discussion}

\subsection{Model Calibration}

Several trial-and-error runs were performed by adjusting $\mathrm{K}_{\text {sat }}$ of soil profile and restrictive bottom layer and maximum surface storage. The model results were the most sensitive, in order, as given in Table 4. Crop rooting depth was also varied to calibrate DRAINMOD (Table 4). Following the soil hydrology calibration, various nitrogen factors were determined using the same approach. Calibrated values are listed in Table 4, which are similar to those given in previous work (e.g., $[21,33,35,51])$.

\subsection{Model Evaluation}

\subsubsection{Field-Scale Tile Discharge}

Figures 1 and 2 show time series graphs of observed and simulated daily tile discharge and precipitation during the calibration and validation periods. Figure 1, showing the calibration period, indicates that measured tile-flow events correspond well with precipitation. DRAINMOD tile-flow peaks almost consistently match the timing of major precipitation events; however, it appears to underestimate more often than overestimate some peak flow values. Please note that DRAINMOD correctly shows no tile flow when precipitation occurs during dry soil conditions in the summer season. A similar pattern is shown in Figure 2 during the validation period. DRAINMOD does a very good job of when tile flow occurs.

The model performance during the calibration and validation stages at daily and monthly time steps are shown in Table 5.

Observed and simulated drain discharge were in close agreement at both daily and monthly time scales during the calibration period. The statistical values given in Table 5 for the monthly time interval are within the acceptable ranges for both NSE $(\geq 0.65)$ and PBIAS $(\leq \pm 15 \%)$, as suggested by [67]. The PBIAS values are very similar for monthly and daily time intervals.

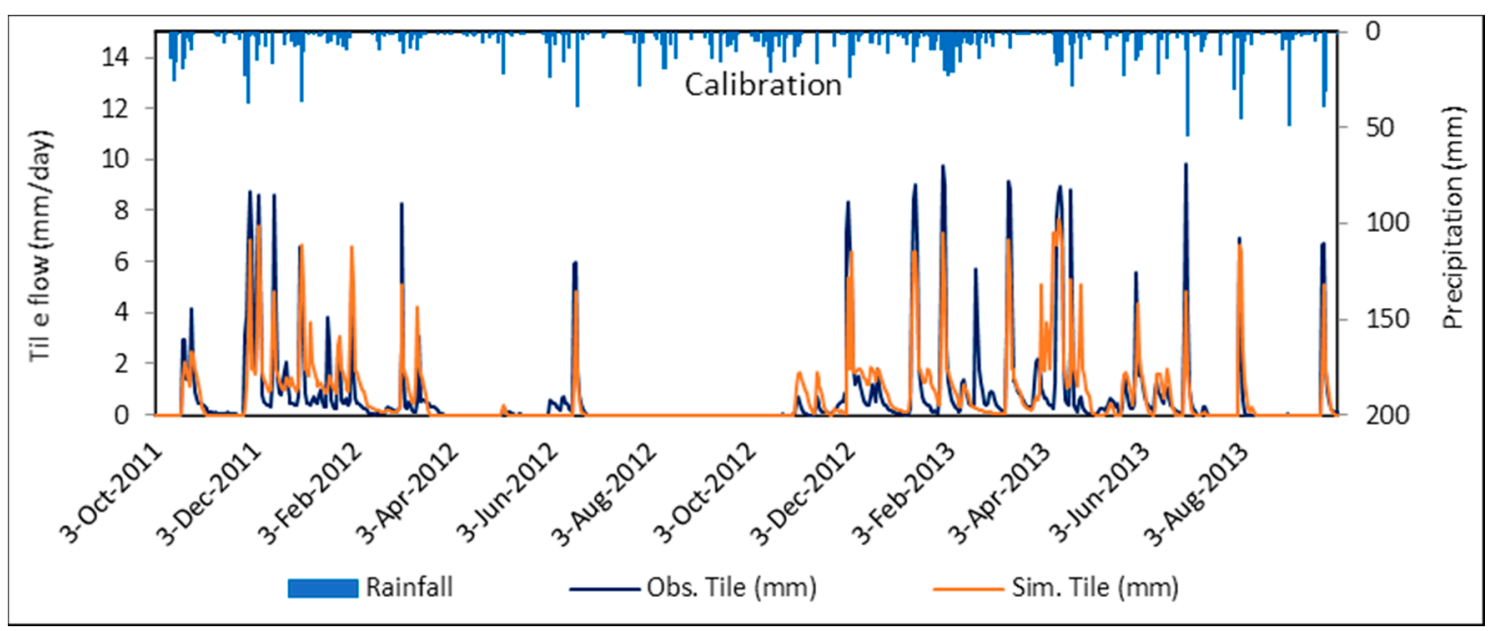

Figure 1. Measured tile discharge (blue line) and precipitation (blue bars) and simulated tile discharge (orange lines) during the model calibration. 


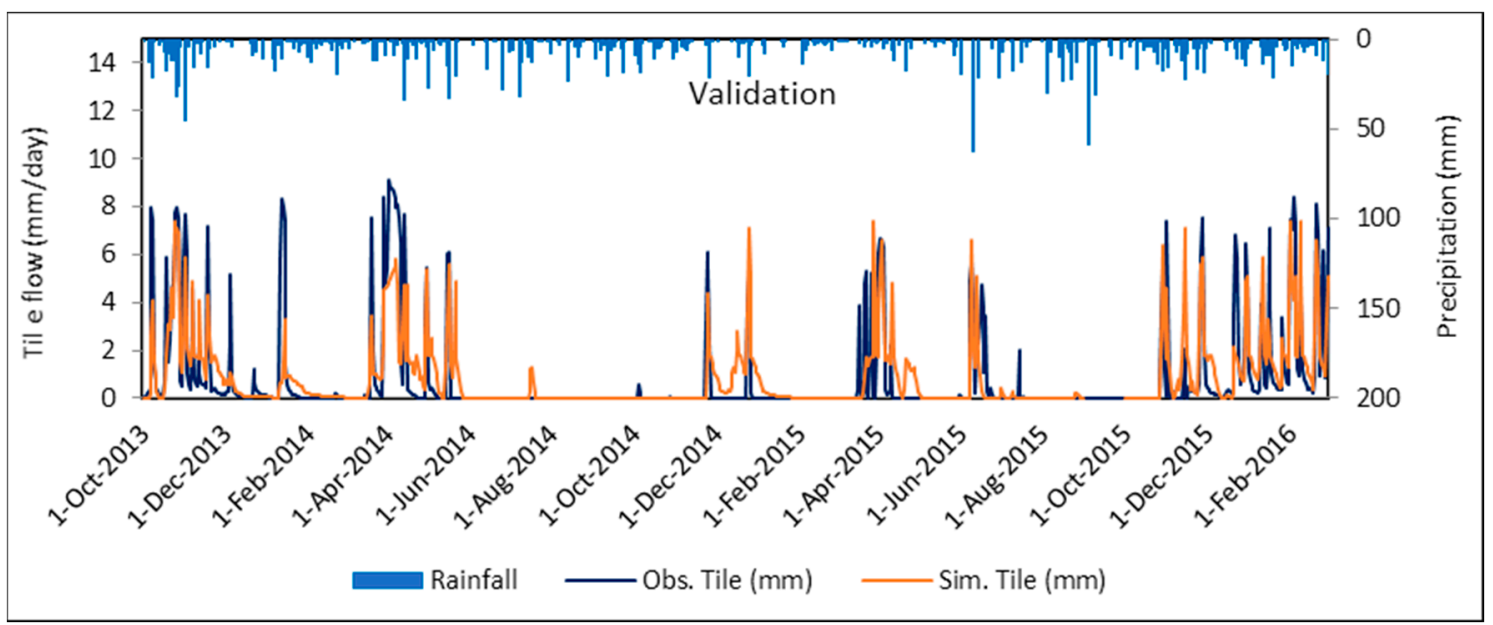

Figure 2. Measured tile discharge (blue line) and precipitation (blue bars) and simulated tile discharge (orange lines) during the model validation.

Table 5. Monthly and daily calibration and validation statistics.

\begin{tabular}{ccccc}
\hline \multirow{2}{*}{ Statistical Index } & \multicolumn{2}{c}{ Monthly } & \multicolumn{2}{c}{ Daily } \\
\cline { 2 - 5 } & Calibration & Validation & Calibration & Validation \\
\hline$R^{2}$ & 0.78 & 0.74 & 0.65 & 0.54 \\
\hline NSE & 0.76 & 0.70 & 0.62 & 0.62 \\
\hline PBIAS (\%) & 1.2 & 1.4 & 1.1 & 1.4 \\
\hline
\end{tabular}

\subsubsection{Field-Scale Nitrogen Yields}

After DRAINMOD was calibrated and validated to successfully simulate tile discharge, a series of nitrogen simulations were done to calibrate the nitrogen component of the model. Ammonium yields were excluded from the model evaluation because both field measurements and model simulations exhibited very small $\mathbf{N H}_{4}^{+}-\mathbf{N}$ yields in tile drain effluent.

The calibration and validation results for daily and cumulative $\mathrm{NO}_{3}-\mathrm{N}$ yields are shown in Figure 3. In general, observed and predicted $\mathrm{NO}_{3}-\mathrm{N}$ yields were in reasonable agreement. During the calibration period, there were two major nitrate-loss events corresponding to significant tile-flow events. The June 2012 nitrate loss occurred during the first major precipitation event following fertilizer application in the spring. However, the major loss of nitrate in April 2013 was not associated with a particular fertilizer application but followed a winter season after corn was grown (Table 2). Figure 3 shows that there is a strong linear relationship between simulated and observed with the coefficient of determination only slightly lower during the validation period than calibration. 


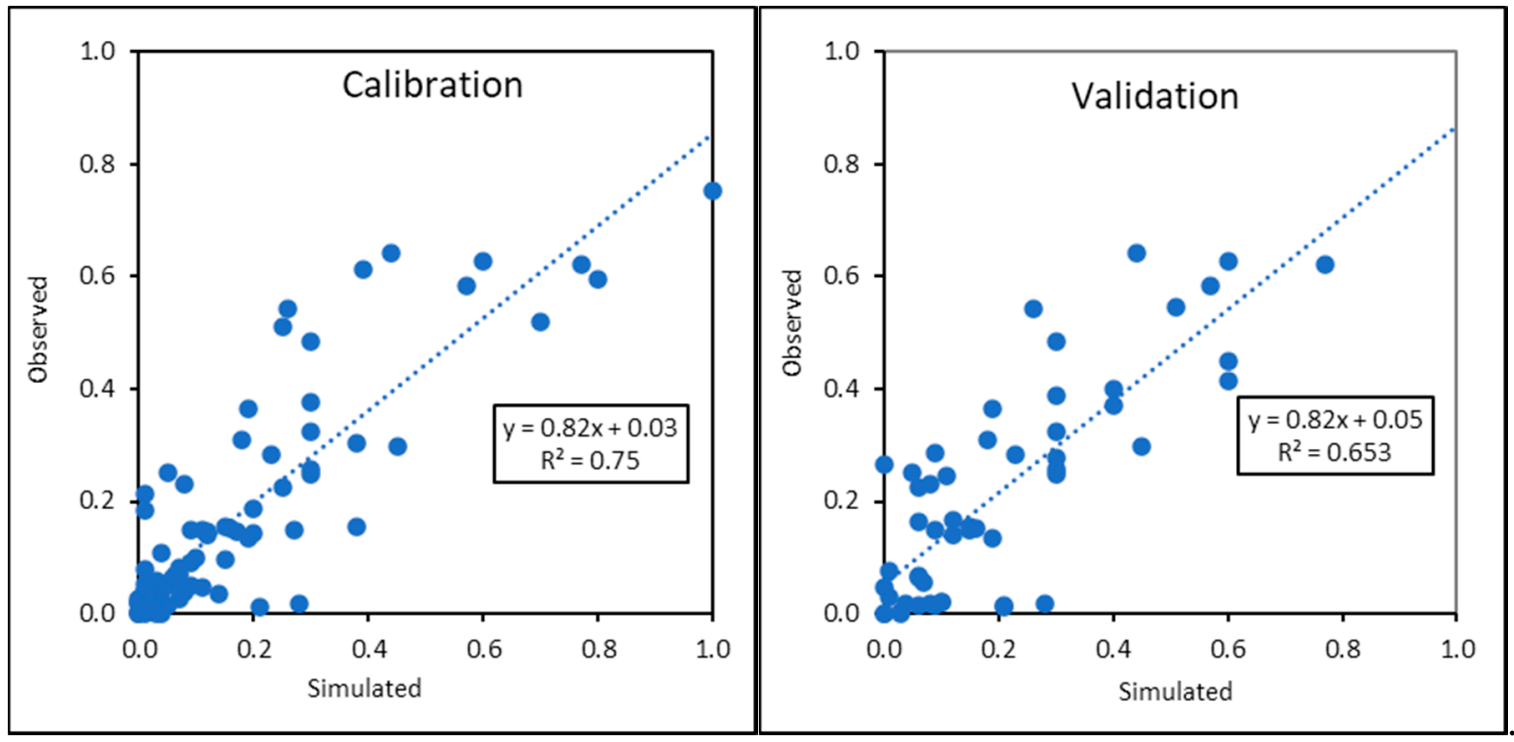

Figure 3. Observed and DRAINMOD-simulated daily $\mathrm{NO}_{3}-\mathrm{N}(\mathrm{kg} / \mathrm{ha})$ from tile outflow at Londesborough field site during calibration (left) and validation (right) periods.

\subsection{Climate Change Analysis}

\subsubsection{Comparing Past and Future Climates}

Figure 4a,d compares annual measured precipitation and DRAINMOD-estimated evapotranspiration for 1960-1990 to three different climate-model estimates of precipitation and DRAINMOD-estimated evapotranspiration for three future time periods. As well, Figure $4 b, c$ compare past-measured and future-estimated daily average maximum and minimum air temperatures using the three different climate models. Please note that both precipitation and evapotranspiration increase in the future as determined in other studies. There are small differences between the three climate-model estimates of precipitation, but model CGCM3T47 does predict somewhat lower future temperature and corresponding evapotranspiration. Therefore, it has been selected as the scenario of future climate change assessment of tile flow and nitrate loss at the site. It represents the least temperature and evapotranspiration increase giving the most predicted future surplus water and, hence, presumably the worst-case scenario for increases in tile flow and corresponding nitrate loss.

Figure 5 shows past and future precipitation and temperature estimates from CGCM3T47 on annual and seasonal bases. Annual precipitation estimates increase with time with a difference of over $20 \%$ from the near- to far-future time periods. Precipitation is divided roughly evenly between seasons; however, summers become slightly drier and other seasons slightly wetter with time. These changes could have significant impacts on reducing crop production in summer and a greater potential for nitrogen loss through denitrification in non-cropping seasons. In terms of average daily temperatures, both minimum and maximum increase in every season almost without exception as time progresses. The summer season appears to show the greatest increase in temperatures from beginning to end of the modeled time period. 

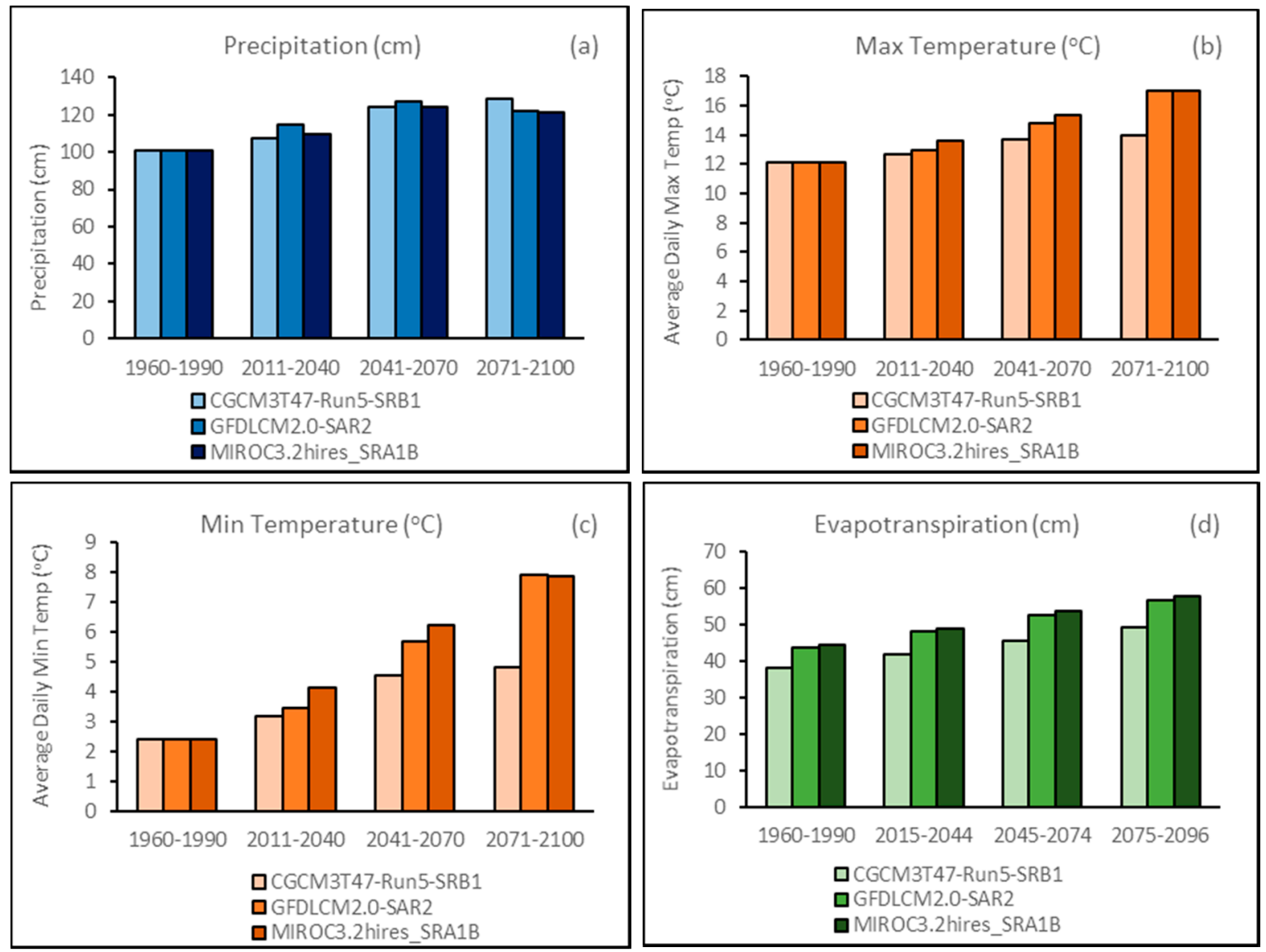

Figure 4. Comparing future climate scenarios ((a) precipitation; (b) maximum average daily temperature; (c) minimum average daily temperature; (d) evapotranspiration) of the three different climate models applied in this study. Please note that for comparison, measured average annual precipitation, average daily maximum and minimum temperatures for 1960-1990 were $100 \mathrm{~cm}, 12^{\circ} \mathrm{C}$ and $2.3^{\circ} \mathrm{C}$, respectively.

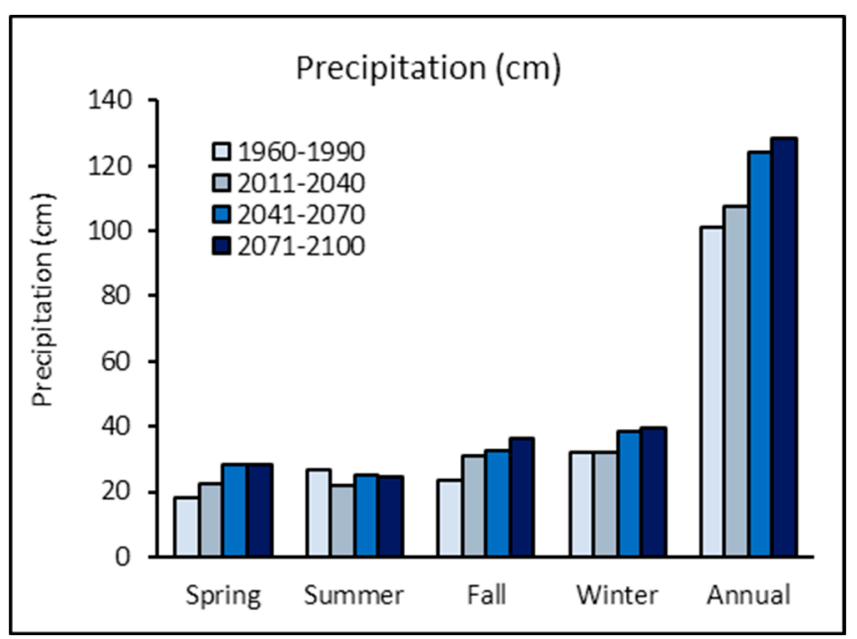

Figure 5. Cont. 

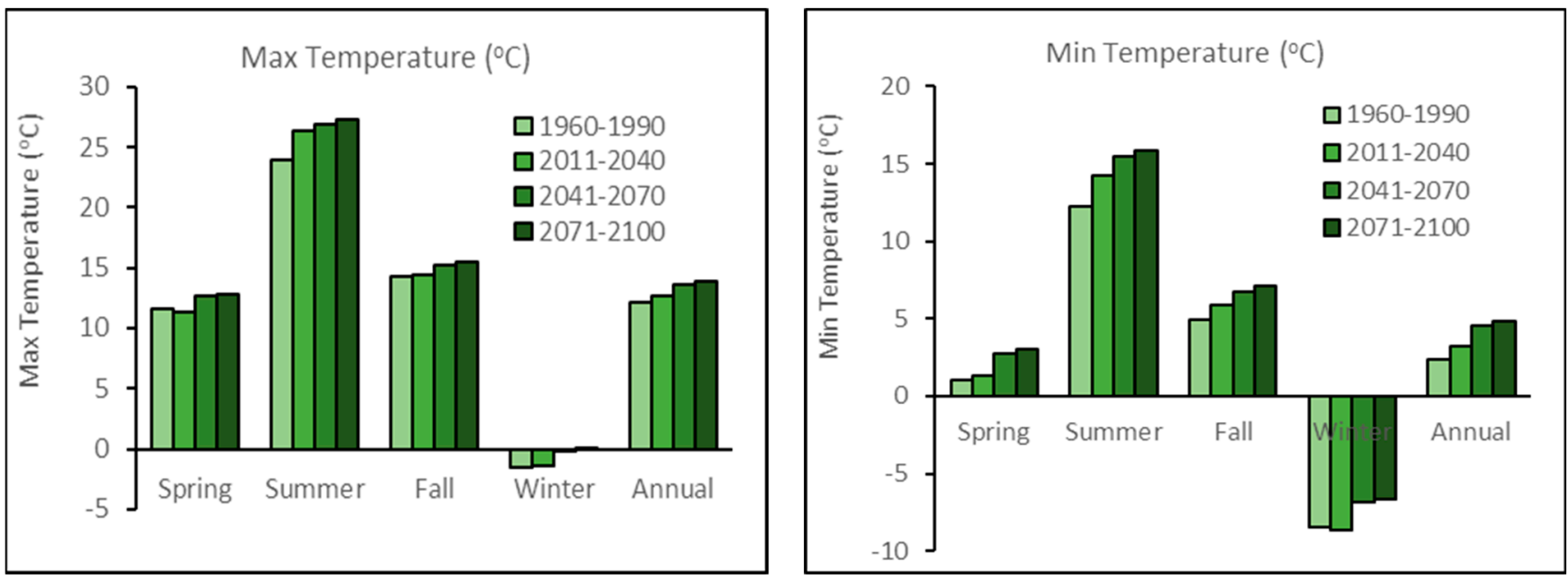

Figure 5. Historical (1960-1990) and future (2011-2100) predicted annual and seasonal mean precipitation (upper figure) and $\mathrm{max} / \mathrm{min}$ daily average temperatures (lower figures) using CGCM3T47 model.

\subsubsection{Effects of Climate Change on Water Balances}

The DRAINMOD model was used to predict the impact of future climates on fieldscale water balance (Figure 6) and the associated nitrate yields from the LON field site in Ontario.

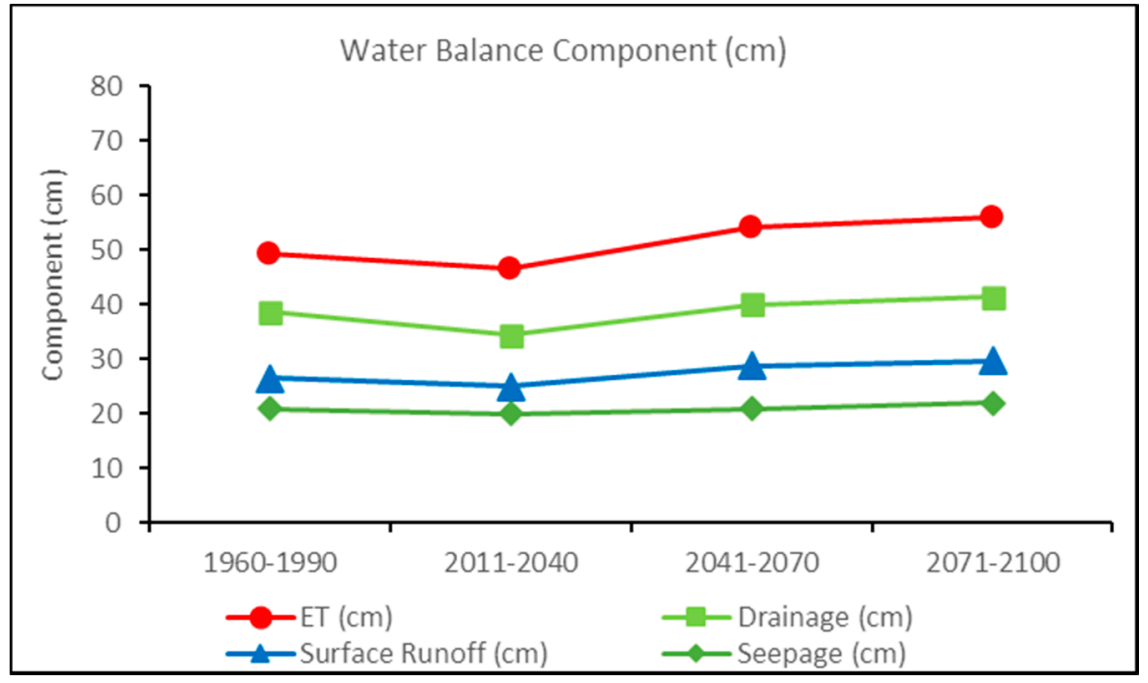

Figure 6. Simulated water balance components for 1960-1990, and 2011-2100 periods.

Evapotranspiration and tile flow first decreased and subsequently increased due to increased precipitation and temperatures under future climate conditions. The comparison of simulated results for the 2071-2100 period (late century) with 1960-1990 period (historical) show that tile flow and ET were found to increase by $7 \%$ and $14 \%$.

\subsubsection{Effects of Climate Change on Tile Discharge and Nitrogen Yields}

Mean seasonal and annual tile discharge for the historical and future time periods is shown in Figure 7. As noted above, the DRAINMOD-estimated annual tile discharge increased slightly during the future period (vs. historical). The winter season appears to dominate this annual increase. The increase in tile flow during winter likely occurs because the estimated maximum daily temperature rises above $0{ }^{\circ} \mathrm{C}$ in the future (Figure 5). This would result in more snow melt and more precipitation occurring as rain. In support of this postulation, [13] predicted that streamflow will increase during winter season in the future 
in several southern Ontario watersheds. As well, [68] found that tile flow is expected to increase based on their study of four Lake Erie watersheds.
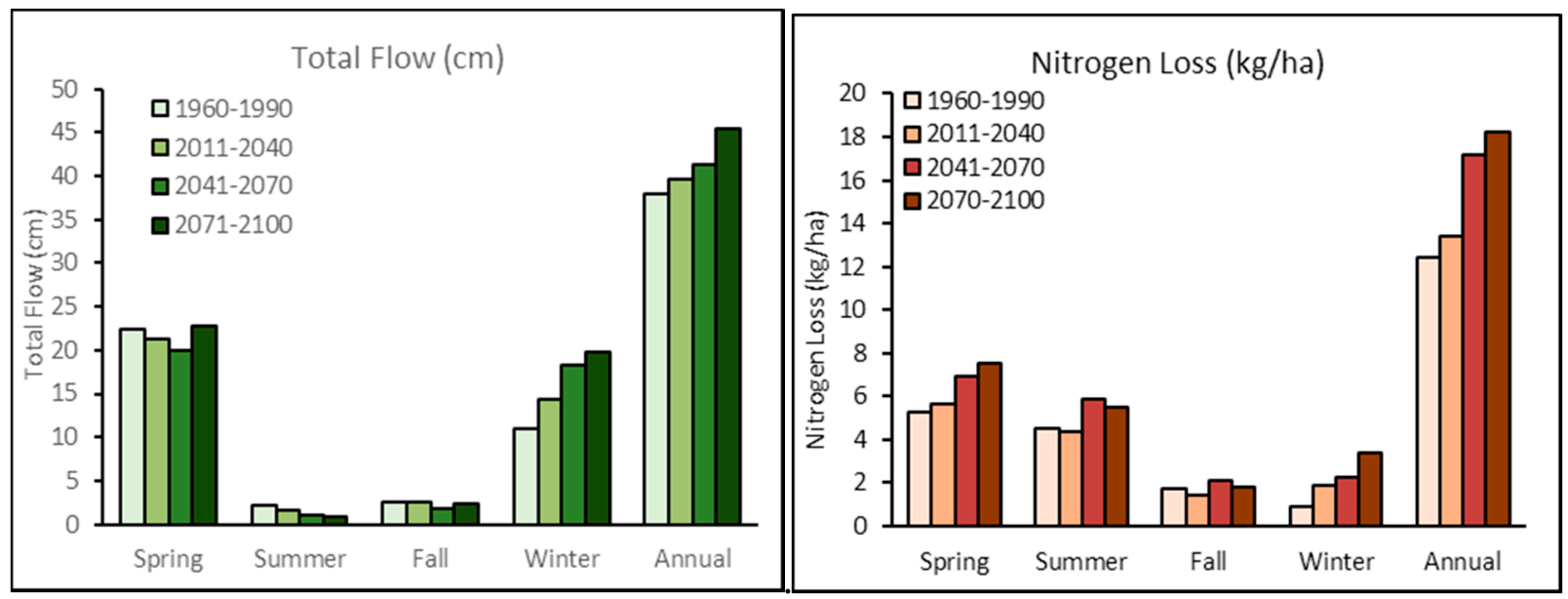

Figure 7. Historical (1960-1990) and future (2011-2100) simulated seasonal and annual average total tile flows (left) and $\mathrm{NO}_{3}-\mathrm{N}$ loss (right).

Figure 7 also shows past and future nitrate loss as estimated by DRAINMOD. Increasing loss in winter season as time progresses matches well with tile-flow estimates. However, the steady increase in nitrate loss in spring does not correspond exactly with tile flow. Average annual estimated tile flow during spring season is variable with time. Hence, the concentration of nitrate must increase in tile water during spring to account for this steady increase in load. Other studies have revealed a range of results. For instance, [69] found very little change in future annual nitrogen loss from watersheds of various sizes in northeastern Indiana. In a study using SWAT model, [70], found that annual P loading would decrease in the future from a watershed in Lake Erie basin due to increased evapotranspiration and decreased snowfall. On the other hand, [14,18,19,68,71,72] all found that nutrient losses may increase in future in Ontario and Quebec watersheds.

\section{Conclusions}

This study has once again shown that DRAINMOD is an effective field-scale model for simulating tile flow in Ontario, Canada. The model calibrated and validated well in comparison to tile-flow measurements collected from a single field site. The calibrated model was used to predict future tile flow and nitrogen loss from the same study site. Tile flow is estimated to increase especially in winter in the future. This result is not uncommon when compared to other studies. However, nitrogen loss appears to be more complicated than tile flow. Although nitrate loss appears to increase consistently with increasing tile flow in the future, increases in nitrate loss through tiles does not correlate well with tile flow. Perhaps an increase in winter and spring season temperatures, especially minimum temperature in spring, is leading to enhanced nitrification and hence excessive nitrate loss during spring.

Author Contributions: Conceptualization, G.G., M.M., R.P.R., G.W.P., P.B.K., P.K.G.; Methodology, G.G., M.M., G.W.P., R.P.R., P.B.K., P.K.G.; Software, G.G., R.P.R., G.W.P., P.K.G.; Formal Analysis, G.G., M.M., G.W.P., R.P.R., P.B.K., P.K.G.; Data Curation, M.M.; Writing—Original Draft Preparation, G.G.; Writing一Review \& Editing, P.K.G., G.W.P., P.B.K., M.M., G.G., R.P.R. Supervision, R.P.R., G.W.P.; Project Administration, G.W.P., M.M.; Funding Acquisition, G.W.P., M.M., R.P.R. All authors have read and agreed to the published version of the manuscript.

Funding: This research received no external funding.

Data Availability Statement: Not Applicable. 
Acknowledgments: The funding received for this project from Ontario Ministry of Agriculture, Food and Rural Affairs (OMAFRA) is gratefully acknowledged.

Conflicts of Interest: The authors declare no conflict of interest.

\section{References}

1. Gorgoglione, A.; Gregorio, J.; Ríos, A.; Alonso, J.; Chreties, C.; Fossati, M. Influence of Land Use/Land Cover on Surface-Water Quality of Santa Lucía River, Uruguay. Sustainability 2020, 12, 4692. [CrossRef]

2. Wang, X.; Zhang, F. Effects of land use/cover on surface water pollution based on remote sensing and 3D-EEM fluorescence data in the Jinghe Oasis. Sci. Rep. 2018, 8, 1-13. [CrossRef]

3. Kändler, M.; Blechinger, K.; Seidler, C.; Pavlů, V.; Šanda, M.; Dostál, T.; Krása, J.; Vitvar, T.; Štich, M. Impact of land use on water quality in the upper Nisa catchment in the Czech Republic and in Germany. Sci. Total Environ. 2017, 586, 1316-1325. [CrossRef]

4. O'Neill, P. Modelling Tile Drains under Present and Future Climate Conditions. Master's Thesis, University of Waterloo, Waterloo, ON, Canada, 2008.

5. Patni, N.K.; Masse, L.; Jui, P.Y. Tile effluent quality and chemical losses under conventional and no tillage. Part1. Flow and Nitrate. Trans. ASAE 1996, 39, 1673-1679. [CrossRef]

6. Sharma, V.; Negi, S.C.; Rudra, R.P.; Yamg, S. Neural networks for predicting nitrate-nitrogen in drainage water. J. Agric. Water Manag. 2003, 63, 169-183. [CrossRef]

7. Wang, Z.; Qi, Z.; Xue, L.; Bukovsky, M. RZWQM2 simulated management practices to mitigate climate change impacts on nitrogen losses and corn production. Environ. Model. Softw. 2016, 84, 99-111. [CrossRef]

8. Sojka, M.; Kozłowski, M.; Kęsicka, B.; Wróżyński, R.; Stasik, R.; Napierała, M.; Jaskuła, J.; Liberacki, D. The Effect of Climate Change on Controlled Drainage Effectiveness in the Context of Groundwater Dynamics, Surface, and Drainage Outflows. Central-Western Poland Case Study. Agronomy 2020, 10, 625. [CrossRef]

9. Jeong, H.; Pittelkow, C.M.; Bhattarai, R. Simulated responses of tile-drained agricultural systems to recent changes in ambient atmospheric gradients. Agric. Syst. 2019, 168, 48-55. [CrossRef]

10. Quilbé, R.; Rousseau, A.; Moquet, J.; Trinh, N.; Dibike, Y.; Gachon, P.; Chaumont, D. Assessing the effect of climate change on river flow using general circulation models and hydrological modelling. Application to the Chaudiere River (Quebec, Canada). J. Can. Water Resour. 2008, 33, 73-93.

11. Prodanovic, P.; Simonovic, S.P. Impacts of changing climatic conditions in the Upper Thames River Basin. Can. Water Resour. J. 2007, 32, 265-284. [CrossRef]

12. Rahman, M.; Bolisetti, T.; Balachandar, R. Hydrologic modelling to assess the climate change impacts in a southern Ontario watershed. Can. J. Civ. Eng. 2012, 39, 91-103. [CrossRef]

13. Champagne, O.; Arain, M.A.; Leduc, M.; Coulibaly, P.; McKenzie, S. Future shift in winter streamflow modulated by the internal variability of climate in southern Ontario. Hydrol. Earth Syst. Sci. 2020, 24, 3077-3096. [CrossRef]

14. Saleem, S.; Levison, J.; Parker, B.; Martin, R.; Persaud, E. Impacts of climate change and different crop rotation scenarios on groundwater nitrate concentrations in a sandy aquifer. Sustainability 2020, 12, 1153. [CrossRef]

15. Wang, L.; Flanagan, D.C.; Wang, Z.; Cherkauer, K.A. Climate change impacts on nutrient losses of two watersheds in the Great Lakes region. Water 2018, 10, 442. [CrossRef]

16. Pease, L.A.; Fausey, N.R.; Martin, J.F.; Brown, L.C. Projected climate change effects on subsurface drainage and the performance of controlled drainage in the Western Lake Erie Basin. J. Soil Water Conserv. 2017, 72, 240-250. [CrossRef]

17. Mehan, S.; Aggarwal, R.; Gitau, M.W.; Flanagan, D.C.; Wallace, C.W.; Frankenberger, J.R. Assessment of hydrology and nutrient losses in a changing climate in a subsurface-drained watershed. Sci. Total Environ. 2019, 688, 1236-1251. [CrossRef]

18. Golmohammadi, G.; Rudra, R.P.; Madani, A.; Goel, P.K.; Mohammadi, K. Modeling the impacts of tillage practices on water table depth, drain outflow and nitrogen losses using DRAINMOD. J. Comput. Electron. Agric. 2016, 124, 73-83. [CrossRef]

19. Hanke, K. Impacts of Climate Change and Controlled Tile Drainage on Water Quality and Quantity in Southern Ontario, Canada. Master's Thesis, University of Waterloo, Waterloo, ON, Canada, 2018.

20. Skaggs, R.W. A Water Management Model for Shallow Water Table Soils; Report No. 134.; Water Resources Research Institute of the University of North Carolina: Chapel Hill, NC, USA, 1978.

21. Youssef, M.A.; Skaggs, R.W.; Chescheir, G.M.; Gilliam, J.W. Field evaluation of a model for predicting nitrogen losses from drained lands. J. Environ. Qual. 2006, 35, 2026-2042. [CrossRef]

22. Skaggs, R.W.; Youssef, M.A.; Chescheir, G.M. DRAINMOD: Model use, calibration, and validation. Trans. ASABE 2012, 55, 1509-1522. [CrossRef]

23. Brown, D.M.; Dadfar, H.; Fallow, D.J.; Gordon, R.J.; Lauzon, J.D.; Parkin, G.W. Temporal and Spatial Variability of Water Surplus in Ontario, Canada. Isrn Soil Sci. 2013, 2013, 362895. [CrossRef]

24. Malota, M.; Senzanje, A. Modelling mid-span water table depth and drainage discharge dynamics using DRAINMOD 6.1 in a sugarcane field in Pongola, South Africa. J. Water Sa 2015, 41, 325-334. [CrossRef]

25. Askar, M.H.; Youssef, M.A.; Chescheir, G.M.; Negm, L.M.; King, K.W.; Hesterberg, D.L.; Amoozegar, A.; Skaggs, R.W. DRAINMOD Simulation of macropore flow at subsurface drained agricultural fields: Model modification and field testing. Agric. Water Manag. 2020, 242, 106401. [CrossRef] 
26. Adhikari, N.; Davidson, P.C.; Cooke, R.A.; Book, R.S. Drainmod-linked Interface for Evaluating Drainage System Response to Climate Scenarios. Appl. Eng. Agric. 2020, 36, 303-319. [CrossRef]

27. Singh, M.; Prasher, S.O.; Tan, C.; Tejawat, C. Evaluation of DRAINMOD for Southern Ontario conditions. Can. Water Resour. 1994, 19, 313. [CrossRef]

28. Shukla, M.B.; Prasher, S.O.; Madani, A.; Gupta, G.P. Field validation of DRAINMOD in Atlantic Canda. J. Can. Agric. Eng. 1994, 36, 205-213.

29. Luo, W.; Skaggs, R.W.; Chescheir, G.M. DRAINMOD modifications for cold conditions. Trans. ASAE 2000, 43, 1569-1582. [CrossRef]

30. Luo, W.; Skaggs, R.W.; Madani, A.; Cizikci, S.; Mavi, A. Predicting field hydrology in cold conditions with DRAINMOD. Trans. ASAE 2001, 44, 825-834.

31. Youssef, M.A.; Skaggs, R.W.; Reynolds, W.R.; Chescheir, G.M.; Gilliam, J.W. Field evaluation of DRAINMOD5.1 using six years of data from an artificially drained agricultural field in North Carolina. In Proceedings of the ASAE Annual International Meeting, Las Vegas, NV, USA, 27-30 July 2003.

32. Yang, C.; Prasher, S.; Wang, S.; Kim, S.; Tan, C.; Drury, C.; Patel, R. Simulation of nitrate-N movement in Southern Ontario, Canada with DRAINMOD-N. Agric. Water Manag. 2007, 87, 299-306. [CrossRef]

33. Salazar, O.; Wesstrom, I.; Youssef, M.A. Evaluation of DRAINMOD-N II model for predicting nitrogen losses in a loamy sand under cultivation in south-east Sweden. J. Agric. Water Manag. 2009, 96, 267-281. [CrossRef]

34. Dayyani, S.; Madramootoo, C.A.; Enright, P.; Simard, G.; Gullamudi, A.; Prasher, S.O.; Madani, A. Field evaluation of DRAINMOD 5.1 under a cold climate: Simulation of daily midspan water table depths and drain outflows. J. Am. Water Resour. Assoc. 2009, 45, 779-792. [CrossRef]

35. Dayyani, S.; Prasher, S.O.; Madramootoo, C.A.; Madani, A. Modeling water table depths, drain outflow, and nitrogen losses in cold climate using DRAINMOD 5.1. Trans. ASABE 2010, 53, 385-395. [CrossRef]

36. Golmohammadi, G.; Prasher, S.O.; Madani, A.; Rudra, R.P.; Youssef, M.A. SWATDRAIN, a new model to simulate the hydrology of agricultural lands, model development and evaluation. J. Biosyst. Eng. 2016, 141, 31-47. [CrossRef]

37. Golmohammadi, G.; Rudra, R.P.; Madani, A.; Goel, P.K.; Mohammadi, K. Modeling the effects of controlled drainage at a watershed scale using SWATDRAIN. Arab. J. Geosci. 2016, 9, 3-7. [CrossRef]

38. Saadat, S.; Frankenberger, J.; Bowling, L.; Ale, S. Evaluation of Surface Ponding and Runoff Generation in a Seasonally Frozen Drained Agricultural Field. J. Hydrol. 2020, 588, 124985. [CrossRef]

39. Skaggs, R.W. DRAINMOD Reference Report. Methods for Design and Evaluation of Drainage Water Management Systems for Soils with High Water Tables; USDA-SCS, South National Technical Report \#329 Center; United States Department of Agriculture Soil Conservation Service: Washington, DC, USA, 1980.

40. Plach, J.M.; Macrae, M.L.; Ali, G.A.; Brunke, R.R.; English, M.C.; Ferguson, G.; Opolko, G. Supply and transport limitations on phosphorus losses from agricultural fields in the lower Great Lakes region, Canada. J. Environ. Qual. 2018, 47, 96-105. [CrossRef]

41. Plach, J.; Pluer, W.; Macrae, M.; Kompanizare, M.; McKague, K.; Carlow, R.; Brunke, R. Agricultural edge-of-field phosphorus losses in Ontario, Canada: Importance of the nongrowing season in cold regions. J. Environ. Qual. 2019, 48, 813-821. [CrossRef]

42. Lozier, T.M.; Macrae, M.L.; Brunke, R.; Van Eerd, L.L. Release of phosphorus from crop residue and cover crops over the non-growing season in a cool temperate region. Agric. Water Manag. 2017, 189, 39-51. [CrossRef]

43. Van Esbroeck, C.J.; Macrae, M.L.; Brunke, R.R.; McKague, K. Surface and subsurface phosphorus export from agricultural fields during peak flow events over the nongrowing season in regions with cool, temperate climates. J. Soil Water Conserv. 2017, 72, 65-76. [CrossRef]

44. Lozier, T. Potential and Observed Release of Phosphorus from Crop Residue and Cover Crops over the Non-Growing Season in a Cool Temperate Region. Master's Thesis, University of Waterloo, Waterloo, ON, Canada, 2016.

45. Pluer, W.T.; Macrae, M.; Buckley, A.; Reid, K. Contribution of preferential flow to tile drainage varies spatially and temporally. Vadose Zone J. 2020, 19, e20043. [CrossRef]

46. Eimers, M.C.; Liu, F.; Bontje, J. Land Use, Land Cover, and Climate Change in Southern Ontario: Implications for Nutrient Delivery to the Lower Great Lakes; Springer: Cham, Switzerland, 2020.

47. Rudra, R.P.; Mekonnen, B.A.; Shukla, R.; Shrestha, N.K.; Goel, P.K.; Daggupati, P.; Biswas, A. Currents Status, Challenges, and Future Directions in Identifying Critical Source Areas for Non-Point Source Pollution in Canadian Conditions. Agriculture 2020, 10, 468. [CrossRef]

48. Van Esbroeck, C.J. Edge of Field Phosphorus Export via Tile Drainage and Overland Flow from Reduced Tillage Systems in Ontario. Master's Thesis, University of Waterloo, Waterloo, ON, Canada, 2015.

49. Hoffman, D.W.; Richards, N.R. Soil Survey of Perth County; Experimental Farms Service; Canada Department of Agriculture and the Ontario Agricultural College: Guelph, ON, Canada, 1952; Volume 15.

50. Youssef, M.A.; Skaggs, R.W.; Chescheir, G.M.; Gilliam, J.W. The nitrogen simulation model, DRAINMOD-N II. Trans. ASABE 2005, 48, 611-626. [CrossRef]

51. Wang, S.; Prasher, S.O.; Patel, R.M.; Yang, C.C.; Kim, S.H.; Madani, A.; Macdonald, P.M.; Robertson, S.D. Fate and transport of nitrogen compounds in a cold region soil using DRAINMOD. J. Comput. Electron. Agric. 2006, 53, 113-121. [CrossRef]

52. Penrod, E.B.; Walton, W.W.; Terrel, D.V. A method to describe soil temperature variation. J. Soil Mech. ASCE 1958, $1537,1-21$. 
53. Gupta, H.V.; Sorooshian, S.; Yapo, P.O. Status of automatic calibration for hydrologic models: Comparison with multilevel expert calibration. J. Hydrol. Eng. 1999, 4, 135-143. [CrossRef]

54. Nash, J.E.; Sutcliffe, J.V. River flow forecasting through conceptual models: Part 1. A discussion of principles. J. Hydrol. 1970, 10, 282-290. [CrossRef]

55. Nakićenović, N.; Swart, R. (Eds.) Special Report on Emissions Scenarios. A Special Report of Working Group III of the Intergovernmental Panel on Climate Change; Cambridge University Press: Cambridge, UK; New York, NY, USA, 2000; p. 599.

56. Das, S.; Millington, N.; Simonovic, S.P. Distribution choice for the assessment of design rainfall for the city of London (ON, Canada) under climate change. Can. J. Civ. Eng. 2013, 40, 121-129. [CrossRef]

57. Chan, A.; Chow, T. Energy and economic performance of green roof system under future climatic conditions in Hong Kong. Energy Build. 2013, 64, 182-198. [CrossRef]

58. Slamova, K.; Koehl, M. Measurement and GIS-based spatial modelling of copper corrosion in different environments in Europe. Mater. Corros. 2017, 68, 20-29. [CrossRef]

59. Wang, X.; Gordon, H. Ontario Climate Change Data Portal. 2013. Available online: http://www.ontarioccdp.ca (accessed on 12 September 2017).

60. Gebremeskel, S.; Liu, Y.B.; de Smedt, F.; Hoffmann, L.; Pfister, L. Analysing the effect of climate changes on streamflow using statistically downscaled GCM scenarios. Int. J. River Basin Manag. 2005, 2, 271-280. [CrossRef]

61. Coulibaly, P.; Shi, X. Identification of the Effect of Climate Change on Future Design Standards of Drainage Infrastructure in Ontario. Ministry of Transportation of Ontario, Highway Infrastructure Innovation Funding Program. 2005. Available online: http:/ / www.cspi.ca/sites/default/files/download/Final_MTO_Report_June2005rv.pdf (accessed on 12 September 2017).

62. Chin, P.; Meyer, P. Orangeville, Mono and Amaranth Water Quantity Risk Management and Climate Change Adaptation Assessment Piolet Study. Report Prepared for Toronto and Region Conservation Authority; Matrix Solutions Inc.: Breslau, ON, Canada, 2014. Available online: https: / / ctcswp.ca/wp-content/uploads/2014/08/RPT_20140829_RMMEP.pdf (accessed on 11 September 2017).

63. Kassenaar, D.; Wexler, E.J. Tier 3 Water Budget and Local Area Risk Assessment for the Region of York. Municipal Supplies-Risk Assessment Report. Prepared for "The Regional Municipality of York Transportation and Works Department"; Earthfx Inc.: 3363 Young St., Toronto, ON, Canada, 2013. Available online: https://www.ctcswp.ca/wp-content/uploads/2017/05/RPT_201311_Earthfx_ York_Tier3WBLocAreaRiskAssFNL.pdf (accessed on 11 September 2017).

64. Sunyer, M.A.; Madsen, H.; Ang, P.H. A comparison of different regional climate models and statistical downscaling methods for extreme rainfall estimation under climate change. Atmos. Res. 2012, 103, 119-128. [CrossRef]

65. Coulibaly, P.; Burn, D.H.; Switzman, H.; Henderson, J.; Fausto, E. A Comparison of Future IDF Curves for Southern Ontario: A Comparison of Future IDF Curves for Southern Ontario. 2016. Available online: https://climateconnections.ca/wp-content/ uploads/2014/01/IDF-Comparison-Report-and-Addendum.pdf (accessed on 12 September 2017).

66. Chiotti, Q.; Tonto, F.; Perun, M. Ontario Regional Adaptation Collaborative Project- Weather and Water Information GatewayGaps Analysis Report. 2012. Available online: http://www.climateontario.ca/doc/ORAC_Products/WaterManagement/Gaps_ Analysis_Report-Final_with_TOC.pdf (accessed on 12 September 2017).

67. Moriasi, D.N.; Arnold, J.G.; Van Liew, M.W.; Bingner, R.L.; Harmel, R.D.; Veith, T.L. Model evaluation guidelines for systematic quantification of accuracy in watershed simulations. Trans. ASABE 2007, 50, 885-900. [CrossRef]

68. Bosch, N.S.; Evans, M.A.; Scavia, D.; Allan, J.D. Interacting effects of climate change and agricultural BMPs on nutrient runoff entering Lake Erie. J. Great Lakes Res. 2014, 40, 581-589. [CrossRef]

69. Wallace, C.W.; Flanagan, D.C.; Engel, B.A. Quantifying the effects of conservation practice implementation on predicted runoff and chemical losses under climate change. Agric. Water Manag. 2017, 186, 51-65. [CrossRef]

70. Kalcic, M.M.; Muenich, R.L.; Basile, S.; Steiner, A.L.; Kirchhoff, C.; Scavia, D. Climate change and nutrient loading in the Western Lake Erie Basin: Warming can counteract a wetter future. Environ. Sci. Technol. 2019, 53, 7543-7550. [CrossRef] [PubMed]

71. Gombault, C.; Madramootoo, C.A.; Michaud, A.R.; Beaudin, I.; Sottile, M.F.; Chikhaoui, M.; Ngwa, F.F. Impacts of climate change on nutrient losses from the Pike River watershed of southern Québec. Can. J. Soil Sci. 2015, 95, 337-358. [CrossRef]

72. Dayyani, S.; Prasher, S.O.; Madani, A.; Madramootoo, C.A. Impact of climate change on the hydrology and nitrogen pollution in a tile-drained agricultural watershed in eastern Canada. Trans. ASABE 2012, 55, 398-401. [CrossRef] 